\title{
BLACK, WHITE OR GREY? - THE CASE OF THE DOUBTFUL TITLE
}

\begin{abstract}
Alan Dowling, School of Law, Queen's University Belfast
The investigation of title carried out on behalf of a purchaser of real property will frequently discover something in the vendor's title that is less than perfect. Often the difficulty will be overcome, by the vendor producing a missing document, or by a third party agreeing to join in the assurance to the purchaser to make good any interest which the purchaser thinks may be outstanding. If however the difficulty cannot be resolved, and the vendor wants to force the contract through, litigation is likely. That litigation may take the form of an action for specific performance by the vendor, or summary proceedings under the Vendor and Purchaser Act. ${ }^{1}$ Either way, if the vendor is to succeed he will have to show his title is good. It might be thought that if the court is not satisfied that the title is good, it must be bad. Simplicity however has never been the most notable feature of property law. Just as things may be neither black nor white, so there is a grey area in the context of the title to land, which conveyancers know as the doubtful title. What is meant is that the vendor may be able to transfer the property he has contracted to sell (in other words, his title may be good), or alternatively he may not (his title may be bad). The matter is in doubt. That doubt may arise for a number of reasons, but whatever the cause may be, there is a question mark over the vendor's ability to convey the property to the purchaser, and the purchaser's ability to enjoy the property in the future without some claim being successfully asserted by a third party against it. Of course, if it is clear that the vendor cannot transfer the land he has contracted to, the title is not doubtful, but simply bad.
\end{abstract}

The courts' approach to cases where the title has been found to be doubtful has been far from consistent. Differences can be seen between what took place in the Courts of Law and in the Court of Chancery, and even in the latter, differences can be found between those judges such as Lord Eldon and Lord Romilly who thought it the business of the court in cases where the title was doubtful that the doubt should be resolved one way or the other, and the title accordingly declared good or bad, and others who give the impression of washing their hands of the problem once it had been shown to exist, leaving it to others to resolve the matter. This note is an account of the oscillations of the pendulum in cases where a doubt as to the vendor's title has been shown to exist.

\section{Suits In Chancery}

In cases in which a vendor finds that his purchaser disputes the title offered, the vendor has to choose whether or not he wants to enforce the contract. If he does, the remedy sought will be specific performance. The practice of the Court of Chancery was that where specific performance was sought, the purchaser had the right to have the title referred to a Master to see if a good

\footnotetext{
1 Vendor and Purchaser Act 1874, s 9.
} 
title could be made by the vendor. As Lord Eldon explained, if the vendor chose not to rely on his right to damages at law, but to seek the aid of the Court of Chancery, the purchaser was entitled not only to have such a title as the abstract revealed, but in consideration of the relief sought beyond the law, to have an assurance about the nature of his title, such as he could not have elsewhere. ${ }^{2}$ Where the title was reported to be good, and assuming there to be no other factors which might influence the court to refuse relief in the exercise or its discretion, the vendor could reasonably expect an order for specific performance to be made: where the title was found to be bad, relief would naturally be refused. The position is both logical and straightforward. Unfortunately, the matter turned out not to be that simple. Although there were judges who took the view that a title was either good or bad, and there was no room for any intermediate position, ${ }^{3}$ this view did not prevail. ${ }^{4}$ The courts came to recognise what was described as a doubtful title: one in other words which might be good or might be bad, according perhaps to the construction to be put upon an instrument upon which the title depended, or to what the law applicable to the case was.

\section{Doubtful Titles}

What is meant by a doubtful title needs to be defined at the outset. The problem is that just as there are bad titles and bad titles, ${ }^{5}$ so there are doubts and there are doubts. The question for the court is what is the value of the objection? ${ }^{6}$ As Kindersley V-C put it in Heseltine v Simmons: " "there was no more difficult question to answer than this: what degree of doubt do you entertain? Is your mind free from doubt? Is it slight? Is it strong, and if so, is it very strong?"

\section{Degrees of doubt}

The quality of title required by the Court of Chancery in suits for specific performance was not perfection: blemishes would be accepted. The purchaser was entitled to a marketable title rather than a perfect one. ${ }^{8}$ This only shifts the question however from being what is a doubtful title, to what is a marketable title? The view expressed by Turner $\mathrm{V}-\mathrm{C}$ in Pyrke $\mathrm{v}$ Waddingham, ${ }^{9}$ that a marketable title is one which can at all times and in all circumstances be forced on an unwilling purchaser, has been approved both

2 Jenkins v Hiles (1802) 6 Ves Jr 646.

3 This was certainly the preference of Lord Eldon LC recalling in Vancouver v Bliss (1805) 11 Ves Jr 458 a period when it was the office of the court to decide whether the title was good or bad. See also the reference in Sloper v Fish (1813) 2 V \& B 145 to the argument that there was no such thing as a doubtful title, and the statement in Eliott v Pott (1821) 3 Bli 134 that Eyre B was of opinion that there was no such thing as uncertainty in the law.

${ }^{4}$ For criticism of the view, as being blind to the facts that the courts were fallible, and that any decision reached would not bind third parties, see In re Edgerley \& Hotrum (1913) 11 DLR 783.

5 Re Scott \& Alvarez's Contract [1895] 2 Ch 603 (Lindley LJ).

6 Grove v Bastard (1848) $2 \mathrm{Ph} 619$ (Cottenham LC).

7 (1858) 6 WR 268.

8 Blosse v Clanmorris (1821) 3 Bli 62.

9 (1852) 10 Hare 1. 
in England ${ }^{10}$ and Australia ${ }^{11}$ but does not give much assistance as to what type of title meets that criterion. More assistance perhaps is to be found in In re Spollon \& Long's Contract ${ }^{12}$ in which Luxmoore $\mathrm{J}$ considered a marketable title as one which would enable the purchaser to sell the property without the need for special conditions of sale restricting investigation by any later purchaser. ${ }^{13}$

On the basis that a purchaser is entitled to a marketable title rather than a perfect one, two questions arise: what is the threshold which determines whether a title which is less than perfect nonetheless constitutes a title which would be forced on an unwilling purchaser; and secondly, who is to be the judge of that? So far as the first question is concerned, a preliminary point may be made that in the situation under consideration the courts are dealing with an unwilling purchaser. In addition to the various classifications of title that have already been mentioned (good, bad, marketable and doubtful) the courts have identified the "good holding title". By this is meant a title which a willing purchaser might reasonably be advised to accept, but which the court will not force on a reluctant purchaser. ${ }^{14}$ In Re Scott \& Alvarez's Contract ${ }^{15}$ Lindley LJ described such titles as bad from a conveyancer's point of view but good from a business man's. The point is that the risk might be acceptable to someone wishing to proceed with the contract, but that in setting the standard for determining whether the title should be forced on a purchaser the courts have done so with someone else in mind. On this basis, any risk to which the purchaser is exposed if the title is forced on him is a risk he has not voluntarily accepted. Understandably therefore the court will not force the title on the purchaser if the title is doubtful. Proceeding on that footing, a title will be a doubtful title if the degree of doubt is sufficiently serious to reach a certain standard. Titles will be doubtful if that standard is attained or that threshold of doubt is crossed. This standard or threshold has been described by the courts in different ways. Thus the threshold which must be crossed for a title to be a doubtful title has been expressed in some cases to be one where there is a "real" doubt; ${ }^{16}$ in others judges have said there must be a "reasonable" doubt, ${ }^{17}$ a "reasonable and fair" doubt, ${ }^{18}$ a "grave and reasonable" doubt, ${ }^{19}$ or a "considerable, rational"

10 Barclays Bank plc v Weeks Legg \& Dean [1998] 3 All ER 213.

11 Pemberton Australia Pty Ltd v CPS Services Pty Ltd 1990 NSW LEXIS 10619. See also Carnana v Duca Community Credit Union Ltd (1994) 20 OR (3d) 563) (Ontario).

12 [1936] Ch 713.

13 See also Williams v Scott [1900] AC 499.

14 Barclays Bank plc v Weeks Legg \& Dean [1998] 3 All ER 213 (Millett LJ).

15 [1895] 2 Ch 603.

16 Playford v Hoare (1829) 3 Y \& J 175; In re Reilly \& Brady's Contract [1910] 1 IR 258.

17 Emery v Grocock (1821) 6 Madd 54; Prosser v Watts (1821) 6 Madd 59; Collard v Sampson (1853) 4 De G M \& G 224; McCullough v Gregory (1856) 3 K \& J 12; Heseltine v Simmons (1858) 6 WR 268; Hamilton v Buckmaster (1866) LR 3 Eq 323; MEPC Ltd v Christian-Edwards [1979] 3 All ER 752; Magennis v Fallon (1828) 2 Moll 561.

18 Lord Braybroke v Inskip (1803) 8 Ves Jr 417; Falkner v The Equitable Reversionary Society (1858) 4 Drew 352.

19 Earl of Lincoln v Arcedeckne (1844) 1 Coll 98. 
doubt. ${ }^{20}$ While the lack or uniformity in the terminology used is unfortunate, it is unlikely that there is any difference in what is intended. Whatever expression is used, there must be a sufficient doubt to render the title one which the court feels should not be forced on the purchaser. ${ }^{21}$ More assistance as to what degree of doubt this signifies may perhaps be found in cases which have identified this degree of doubt with the danger of the purchaser being involved in litigation to defend his title should it be forced on him by the court. ${ }^{22}$ If the court thinks there is a "reasonable decent probability of litigation", ${ }^{23}$ then the title is not one in respect of which the court should order specific performance. Where the risk to the purchaser is less than that, the vendor can expect an order for specific performance to be made. Just as the courts have used different expressions to characterise the degree of doubt required to make a title a doubtful title, so different expressions have been employed to characterise the degree of risk which will yet allow the court to order specific performance: where the risk is "theoretical", ${ }^{24}$ "theoretical or fanciful", ${ }_{25}$ "fanciful or idle", ${ }^{26}$ "purely imaginary", 27 "shadowy or frivolous", 28 "so remote or so shadowy as to be one to which no serious attention need be paid", ${ }^{29}$ "non-existent",

20 Stayplton v Scott (1809) 16 Ves Jr 272.

21 It has been said that the court must govern itself by a moral certainty, there being no such thing as a mathematical certainty of a good title (Lydall v Weston (1739) 2 Atk 19 (Lord Loughborough LC)) though this was explained to mean only that a title cannot be proved by means of reasoning but only with the help of evidence (Hutchinson v Morritt (1839) 3 Y \& C Ex 547 (Alderson B)). Lord Eldon once memorably remarked that the cases had gone as far almost to suppose the title would not be good unless the court was willing to spend $£ 95,000$ of its own money on the title (Jervoise v Duke of Northumberland (1820) 1 Jac \& W 559). The comment of Alderson B in Hutchinson v Morritt that these sort of apothegms get a great deal more weight than they deserve should be noted. In cases where the title depends on a matter of fact, it has been said that if a judge would be under a duty to give a direction in favour of the jury presuming the fact, the title is beyond reasonable doubt, whereas if the judge were bound to leave it to the jury to pronounce on the effect of the evidence, the title is too doubtful to conclude a purchaser: Emery v Grocock (1821) 6 Madd 54 (Leach V-C), approved in MEPC Ltd v Christian-Edwards [1978] 3 All ER 795, though in the latter case on appeal to the House of Lords ([1979] 3 All ER 752), Lord Russell doubted whether the case could be brought within the principle as so enunciated.

22 See also Price v Strange (1820) 6 Madd 159, where it is said the purchaser will not be compelled to take a title which he can only obtain in possession by litigation and judicial decision.

23 Cattell v Corrall (1840) 4 Y \& C Ex 228; In re New Land Development Association and Gray [1892] 2 Ch 138; In re Marshall \& Salt's Contract [1900] 2 Ch 202; Darvell v Basildon Development Corpn (1969) 211 EG 33; In re Walker \& Elgee's Contract (1918) 53 ILTR 22; Re Pigott \& Kern (1913) 12 DLR 838; EPC Industries Ltd v Union Electric Supply Co Ltd (1985) unrep (Newfoundland SC); Carnana v Duca Community Credit Union Ltd (1994) 20 OR (3d) 563.

24 In re Heaysman \& Tweedy's Contract (1893) 69 LT 89; In re Summerson [1900] 1 Ch 112; Free Focus Ltd v Fels China Ltd 1989-2 HKC 568.

25 Coastland Properties Pte Ltd v Ho San Kong Hoey 1998-3 SLR 147.

${ }^{26}$ Lion Will Investment Ltd v Triple Will Ltd 1992-2 HKC 430.

27 Mogridge v Clapp [1892] 3 Ch 382.

28 Heseltine v Simmons (1858) 6 WR 268.

29 Manning v Turner [1956] 3 All ER 641; Barclays Bank plc v Weeks Legg \& Dean [1998] 3 All ER 213. 
"ridiculous", or such that the case "would be laughed out of court", ${ }^{30}$ then the title is not doubtful and the vendor can expect specific performance to be ordered. ${ }^{31}$ Perhaps the clearest enunciation of the test applicable is that by Lord Russell in MEPC Ltd v Christian-Edwards ${ }^{32} v i z$, that if the facts and circumstances of the case are so compelling to the mind of the court that the court concludes beyond reasonable doubt that the purchaser will not be at risk of a successful assertion against him of the incumbrance, the court should declare in favour of the title shown.

The second of the two questions mentioned earlier is who is to judge whether the doubt is sufficient to be a reasonable doubt? Beauty is in the eye of the beholder, and a doubt will be a reasonable doubt according to the diffidence of the conveyancer concerned. ${ }^{33}$ Cautious practitioners, with one eye perhaps on their insurance policy, may consider titles doubtful where others may find something which is not perfect, but which they see as giving rise to no real concern as to the safety of the title to the purchaser. On the assumption that the purchaser wants to proceed with the purchase and is not raising doubts simply as a means of getting out of the contract, ${ }^{34}$ any queries he has will be reasonable ones in his own mind (or that of his solicitor). The simple answer of course, as Lord Russell pointed out, is that the doubt must be a reasonable one in the mind of the judge who is called on to consider the title and the doubt raised by the purchaser. That unfortunately puts the matter little forward, as the authorities appear to show some judges more cautious than others in their approach to questions of this sort. ${ }^{35}$ In some of the cases judges have taken the view that their own opinion should be taken to be right, ${ }^{36}$ while in others judges have considered doubts reasonable because other judges could take different views. ${ }^{37}$ The matter is particularly obvious in cases where an appeal is made against an order either that the contract be specifically performed or a refusal of such an order. If the appellate court

30 Yook Lu Fong v Lau Po Ching 2002-2 HKC 657.

31 For cases in which the risk was considered sufficient that specific performance was refused, see Lowes v Lush (1808) 14 Ves Jr 547; Franklin v Lord Brownlow (1808) 14 Ves Jr 500; In re New Land Development Association \& Gray [1892] 2 Ch 138; Re Poppleton \& Jones' Contract (1896) 74 LT 582 (all involving the threat of a claim by a trustee in bankruptcy); Re Hollis' Hospital Trustees \& Hague's Contract [1899] 2 Ch 540; In re Marshall \& Salt's Contract [1900] 2 Ch 202; Re Pigott \& Kern (1913) 12 DLR 838 (for subsequent history see Pigott v Bell (1913) 5 OWN 314; McNivin v Pigott (1914) 19 DLR 846; (1914) 22 DLR 141; (1915) 22 DLR 147); EPC Industries Ltd v Union Electric Supply Co Ltd (1985) unrep (Newfoundland SC). For cases falling the other side of the line, see Cattell v Corrall (1840) 4 Y \& C Ex 228; Mogridge v Clapp [1892] 3 Ch 382; Re Heaysman \& Tweedy's Contract (1893) 67 LT 89; Re Calcott \& Elvin's Contract (1898) 67 LT 327; In re Summerson [1900] 1 Ch 112; Hepworth v Pickles [1900] $1 \mathrm{Ch} 108$.

32 [1979] 3 All ER 752.

33 See the comments of Lord Romilly MR in Mullings v Trinder (1870) LR 10 Eq 449.

34 See Lo Tai Yam v Hu Mu Simon 1997-3 HKC 23.

35 A point recognised in Lamb v Allison (1890) 11 NSWR 23.

36 See Bell v Holtby (1873) LR 15 Eq 178 (Malins V-C).

37 Eg Rogers v Waterhouse (1858) 4 Drew 329 (Kindersley V-C); Cook v Dawson (1861) 3 De G F \& J 127; Sykes v Sheard (1863) 12 WR 117 (Turner LJ); In re Thackwray \& Young's Contract (1888) 40 Ch D 34 (Chitty J). 
takes a different view to that of the trial judge, is there not by definition a case where the title is doubtful? In some of the authorities appeal judges have refused to interfere with the order appealed against unless of the view that the judge who made the order was clearly wrong, suggesting that the order should be upheld even though the appeal judge would not have made the same order had he been the trial judge. The problem with this approach however was made clear in Sheppard v Doolan ${ }^{38}$ in which Sugden LC explained that it effectively disregarded the appeal structure which had been established and made the view of the lower court determinative of the issue.

\section{Sources of doubt}

Doubts which render titles doubtful ones may arise in different ways. ${ }^{39}$ The courts have identified a number of sources of doubt in such cases. There may be a doubt because the law itself is in doubt, for example where the validity of a title depends on a point of law and there are conflicting decisions of the courts on the point. Secondly, there may be a doubt because although the law may be certain, its application in the circumstances of the case is not. A possible cause is where the title depends on construction of an instrument and there is more than one construction of the instrument possible. In most of the cases falling into this category the property in question has been devised by will, and the doubt has arisen because of the possibility that the will could be construed so that another party could have become entitled to it. Wills are by not means however the only case where titles have been considered doubtful because the matter turns on construction: the problem may arise in the case of any private instrument or a statutory provision. Finally, the doubt may arise because the title depends on certain facts and those facts are in doubt, as for example where the property had many years earlier been agreed for sale to a third party, and it was doubt as to what had happened thereafter, ${ }^{40}$ or where the title depends on whether or not someone was affected by notice of some act or instrument. ${ }^{41}$ In all these cases where a doubt arises on the title, it is of course possible for the vendor to preclude the purchaser from raising the doubt by appropriately drafted conditions of sale in the contract between the parties. ${ }^{42}$ So long as the vendor fulfils his duty of disclosure and the condition is not misleading, the vendor should be able to obtain specific performance notwithstanding the problem with the title. ${ }^{43}$

38 (1842) 3 Dr \& War 1.

39 See Howarth v Smith (1833) 6 Sim 161.

40 MEPC Ltd v Christian-Edwards [1979] 3 All ER 752.

41 Freer v Hesse (1853) 4 De G M \& G 495; Nottingham Patent Brick \& Tile Co v Butler (1886) 16 QBD 778; In re Handman \& Wilcox's Contract [1902] 1 Ch 599. Note however the view of Lord Romilly MR in Mullings v Trinder (1870) LR 10 Eq 449 that where the facts on which the title depends are in doubt specific performance is refused not because the title is doubtful, but because the vendor has failed in his obligation to prove his title is good.

42 See Best v Hamand (1879) 12 Ch D 1.

43 Becker v Partridge [1966] 2 All ER 266. The extent of the principle can be seen in cases in which the court has ordered specific performance of contracts containing provisions precluding the purchaser from making any requisition as to the title of the vendor: see Duke v Barnett (1846) 2 Coll 337; Hume v Bentley (1852) 5 De G \& Sm 520; Hume v Pollock (1866) LR 1 Ch 379. 


\section{Possible Courses Of Action}

Having recognised the existence of a category of title known as a doubtful title the question was what should be done by the court in cases where the court was asked by the vendor for an order for specific performance of a contract for the sale of land the title of which was doubtful. Several possible courses of action were open to the court in such cases.

\section{Declare title good or bad}

The first possible course was to avoid the problem altogether by declaring that the title was not doubtful at all, but either good or bad. Such course could logically take place only on appeal, as in the situation under consideration we are supposing a title considered doubtful by the trial judge.

\section{Resolve the doubt}

A second possible course of action was to resolve the doubt and declare the title good or bad. The difference between this and the previous alternative is that here the court recognises that the title is doubtful, but then disposes of the doubt. As we will see, for a considerable period the Court of Chancery refused to adopt this course. A number of reasons for not resolving the doubt, but instead, for simply refusing to make an order for specific performance, have been mentioned in the authorities. First, and perhaps most significantly, any decision made by the court would be binding on the parties to the suit only (the vendor and purchaser) and would not preclude any third party from showing at a later date that the title was in fact bad. ${ }^{44}$ Thus in a case depending on the construction of a will, any determination in favour of the vendor would not guarantee safety for the purchaser should any third party later be able to show that on the true construction of the will the property had not passed to the vendor or his predecessors in title. A second reason for the court refusing to resolve the point was related to this: the court would be deciding a point in the absence of argument from parties potentially interested in the result. ${ }^{45}$ A third reason for refusing to determine the point was that should any litigation ensue after the title had been forced on the purchaser, the purchaser might lack knowledge of facts relevant to determining whether the title was good or bad, and so be unable effectively to defend any action brought by a third party. ${ }^{46}$ The same reasoning applied

44 Cooper v Denne (1792) 4 Bro CC 80; Jenkins v Harries (1819) 6 Sim 168; Macdonald v Walker (1851) 14 Beav 556; Pyrke v Waddingham (1852) 10 Hare 1; Osborne to Rowlett (1880) 13 Ch D 774. In cases where the third party is before the court the problem may be solved: see Darvell v Basildon Development Corpn (1969) 211 EG 33; Valoutin Pty Ltd v Furst [1998] 339 FCA; Yook Lu Fong v Lau Po Ching 2002-2 HKC 657. In Wilson v Thomas [1958] 1 All ER 871 the possibility of a representation order is suggested as a means whereby the court could proceed to resolve the doubt in the proceedings between the vendor and the purchaser where some but not all of those who could assert a claim against the property are before the court.

45 Green v Pulsford (1839) 2 Beav 70; Glass v Richardson (1852) 9 Hare 698; Poole v Coates (1842) 2 Dr \& War 493.

46 Hartley v Smith (1819) Buck 368; Emery v Grocock (1821) 6 Madd 54; Howarth v Smith (1833) 6 Sim 161; Pyrke v Waddingham (1852) 10 Hare 1; Nottingham Patent Brick \& Tile Co v Butler (1881) 16 QBD 778; In re Douglas \& Powell's 
to the proceedings between the vendor and the purchaser: the purchaser was unlikely to have the information necessary to counter the vendor's case, where this depended on matters of fact, or the means of acquiring it. ${ }^{47}$ Other reasons expressed in some of the authorities for adopting the practice of refusing to order specific performance where the title was in doubt are that the court was reluctant to force a title on the purchaser which the court could not warrant ${ }^{48}$ and when it had no means of indemnifying the purchaser should it later turn out that the title was bad. ${ }^{49}$ Finally, in Fildes v Hooker ${ }^{50}$ Grant MR considered it would be unreasonable to order the purchaser to perform the contract while at the same time not ensuring that the vendor was in a position to perform his side of the bargain by transferring title to the property.

\section{Refuse specific performance}

The course which was for a long time adopted by the court in suits for specific performance where the title was doubtful was for the court to refuse to make the order, and thereby to leave the vendor to whatever remedy he could obtain in the Courts of Law should the purchaser refuse to complete the contract. ${ }^{51}$ Refusal of an order for specific performance did not avoid the contract, and the vendor could forfeit the deposit or seek damages if the purchaser refused to complete, ${ }^{52}$ unless the purchaser could show some right to terminate the contract. The reasons for adopting this course were those identified above. The principle that a purchaser was not obliged to buy a law suit was articulated from time to time in support of the practice. By definition, the title was doubtful because there was more than one possible way of looking at it. Some might think the title sound, others might not. In refusing to determine the point, the court was stating its acceptance of the position, rather than asserting its own ability to resolve the doubt, certainly at least in the absence of argument from third parties who might be interested. In some cases where the court considered the title was doubtful, and so refused specific performance, judges refused to state their own views as to

Contract [1902] 2 Ch 296; In re Handman \& Wilcox's Contract [1902] 1 Ch 599. See also Wilson v Thomas [1958] 1 All ER 871.

47 See Wilson v Thomas [1958] 1 All ER 871.

48 Lowes v Lush (1808) 14 Ves Jr 547.

49 Sheffield v Lord Musgrave (1795) 2 Ves Jr 526; Pyrke v Waddingham (1852) 10 Hare 1.

50 (1817) 2 Mer 424.

51 The authority cited by Williams (Williams, Law of Vendor and Purchaser (3rd ed, 1922 , p 1036) for the proposition that where specific performance is refused because the title is doubtful the vendor may pursue remedies at law is Cooper v Denne (1792) 1 Ves Jr 565. The case was however settled after specific performance was refused, and the dictum upon which reliance seems to be placed does not appear in the other report of the case (4 Bro CC 80). Nonetheless, the principle that where specific performance is refused in the exercise of the court's discretion the plaintiff may proceed at law is established by the authorities cited in the footnote following.

52 See Beere v Fleming (1862) 13 ICLR 506; Mortlock v Buller (1804) 10 Ves Jr 292; Wedgwood v Adams (1844) 8 Beav 103; Webster v Cecil (1861) 30 Beav 62. 
the title, ${ }^{53}$ while in others judges made it known that they thought the title might be sound. ${ }^{54}$

\section{Await decision elsewhere}

Finally, in some cases it was possible for the court to avoid making a determination in the suit for specific performance until the doubt was resolved elsewhere. Thus we find the court sending a case to the Courts of Law for a certificate on facts presented to them. ${ }^{55}$ The value of such certificate however was evidential only, and doubts might remain when the matter came back to the Court of Chancery so that specific performance could still be refused. ${ }^{56}$ In one case the court adjourned the suit to see if any action was brought by a third party which would effectively determine whether the title was good or bad, thereby avoiding any difficulties in making or refusing an order for specific performance. ${ }^{57}$ In another case a suit was adjourned to await the result of rectification proceedings which would have a similar effect. ${ }^{58}$ Finally, in some cases where the doubt arose because of construction of a will, the practice of adjourning the suit to allow a summons to be taken out in which the true construction of the will would be determined between the parties possibly interested under the will was adopted. ${ }^{59}$

\section{The Practice Of The Court}

\section{Changes in approach}

The course of action adopted by the Court of Chancery in suits for specific performance varied. Originally, the practice of the Court was to declare the title either good or bad, and grant or refuse specific performance accordingly. A party dissatisfied with the decision was left to appeal to the House of Lords, and while a decision of the Lords would not be conclusive, in that third parties would not be bound by it, the decision was considered in

53 See eg Wilcox v Bellaers (1823) T \& R 491; Cowgill v Lord Oxmantown (1839) 3 $\mathrm{Y} \& \mathrm{C}$ Ex 369

54 See eg Pyrke v Waddingham (1852) 10 Hare 1; Rogers v Waterhouse (1858) 4 Drew 329, Collier v McBean (1865) LR 1 Ch 81; In re Bramwell's Contract [1969] 1 WLR 1659; Magennis v Fallon (1828) 2 Moll 561; Stewart v Marquis of Conyngham (1849) 1 Ir Ch R 534. See also Rose v Calland (1800) 5 Ves Jr 186, Lord Loughborough LC refusing specific performance because of a decision of the Court of Exchequer, though he thought the decision questionable.

55 Sheffield $\mathrm{v}$ Lord Musgrave (1795) 2 Ves Jr 526; Trent v Hanning (1805) 10 Ves Jr 495; Husker v Sutton (1826) 2 Sim \& St 513; Sheppard v Doolan (1842) 3 Dr \& War 1.

56 Sheffield v Lord Musgrave (1795) 2 Ves Jr 526.

57 George v Thomas (1904) 90 LT 505.

58 Bentley v Craven (1853) 17 Beav 204.

59 In re Nichols \& Von Joel's Contract [1910] 1 Ch 43; In re Hogan \& Marnell's Contract [1919] 1 IR 422. See also Cameron v Hull (1913) 9 DLR 843. For an earlier instance of the court adopting a similar practice see Grove v Bastard (1848) $2 \mathrm{Ph} 619$ in which the suit was stood over to allow the validity of the will to be established between the vendor and the heir of the testator, the court holding Green v Pulsford (1839) 2 Beav 70 as authority for the proposition that the court would do so before requiring the purchaser to accept the title. 
practice a sufficient warranty of the title to be relied on. ${ }^{60}$ This practice changed however during the course of the eighteenth century, and for the next hundred years or so it became the practice that the Court would refuse to order specific performance in cases where the title was considered doubtful, and instead would leave the parties to their remedies at law. According to Lord Eldon, the change in practice was heralded by Shapland $\mathrm{v}$ Smith ${ }^{61}$ though it seems in fact to have begun before then. In Sloper v Fish ${ }^{62}$ Grant MR said the practice could be traced back to Jekyll MR's time, Marlow v Smith ${ }^{63}$ being a case in point. Again, in Mitchell v Neale ${ }^{64}$ specific performance was refused by Lord Hardwicke, the Lord Chancellor saying that he was dealing with the case "of a purchaser of an estate, whom no court of justice will compel to accept upon any doubtful title."

The new practice of refusing specific performance in cases where the title was doubtful was criticised by Lord Eldon, ${ }^{65}$ who reluctantly came however to accept it, and the practice continued apparently quietly ${ }^{66}$ until the middle of the nineteenth century when Romilly MR signalled a different approach to cases where title was doubtful. This approach was at notable variance with that of Sir George James Turner, initially Vice-Chancellor and later Lord Justice of the Court of Appeal in Chancery. ${ }^{67}$ The views of the Vice-

60 See the explanation by Lord Eldon LC in Vancouver v Bliss (1805) 11 Ves Jr 458 and Jervoise v Duke of Northumberland (1820) 1 Jac \& W 559.

61 (1780) 1 Bro CC 75. The proceedings involved consideration of exceptions to a report by a Master in favour of the title, and the case was initially heard by Eyre B (on behalf of the Lord Chancellor) and Masters Holford and Hett. The cause was stood over and reheard by Lord Thurlow LC in view of the disagreement between Eyre B and Master Holford (who were in favour of the title) on the one hand and Master Hett on the other. Lord Thurlow LC agreed with Master Hett but said that if the title were doubtful, specific performance would not be ordered. In Eliott v Pott (1821) 3 Bli 134 it is said that Eyre B was "a good deal shocked" by the decision, being of opinion that there was no such thing as uncertainty in the law. Vesey reports him in Cooper v Denne (1792) 1 Ves Jr 565 as saying the decision was liable to criticism, though the principle that the court should not enforce a doubtful title is affirmed.

62 (1813) 2 V \& B 145.

63 (1723) 2 P Wms 198.

64 (1755) 2 Ves 679.

65 See Vancouver v Bliss (1805) 11 Ves Jr 458; Stapylton v Scott (1809) $16 \mathrm{Ves} \mathrm{Jr}$ 272; Jervoise v Duke of Northumberland (1820) 1 Jac \& W 559. See also comments in Colmore v Tyndall (1827) 2 Y \& J 605 and Magennis v Fallon (1828) 2 Moll 561.

66 In Biscoe v Perkins (1813) 1 V \& B 485 Lord Eldon ordered specific performance, saying that that he would compel the purchaser to take the title unless the purchaser reversed the Lord Chancellor's opinion (by an appeal to the House of Lords), this being the former practice. See also Biscoe v Wilks (1817) 3 Mer 456. The attempt to reintroduce the old practice did not succeed, and the courts continued to refuse to order specific performance where the title was doubtful.

67 The Court of Appeal in Chancery was established in 1851 to hear inter alia appeals against decisions of the Master of the Rolls. As such, the opportunity arose for the differing approaches of Lord Romilly MR and Turner LJ to come into conflict. As might be expected, the more cautious approach of Turner LJ (sitting with Knight Bruce LJ, another former Vice-Chancellor) was unlikely to mean that decisions in which the Master of the Rolls had refused specific performance would be reversed. Where specific performance had been ordered by 
Chancellor, expressed in Pyrke v Waddingham ${ }^{68}$ and maintained by him after his appointment as Lord Justice, ${ }^{69}$ were, in summary, that it was the duty of the court not to have regard to its own opinion only, but to take into account what the opinion of other competent persons might be; and that even though the court was of opinion in favour of the title, it did not follow that specific performance should be granted, bearing in mind that the remedy was discretionary and that there was no means of binding third parties or of indemnifying the purchaser should the court's view turn out not to be correct. Where the doubt concerning the title arose as to a matter of law, the court had to consider whether the point was settled or not, granting specific performance in the one case and refusing it in the other. In construction cases, if the court was in doubt as to the construction, specific performance should be refused, even though the court leant in favour of the title. In cases where the point depended on extrinsic evidence which neither the purchaser nor the court had the means of investigating, specific performance was to be refused.

The difference in approach of Romilly MR, referred to above, in cases where the title was questionable can be seen in Wrigley v Sykes ${ }^{70}$ and Spencer v Topham ${ }^{71}$ but is more explicit in Bull $\vee$ Hutchens ${ }^{72}$ in which the Master of the Rolls said that Turner V-C had not intended his observations in Pyrke v Waddingham to extend so far as to lay down that whenever there was a reasonable doubt as to the validity of an objection the purchaser should not be compelled to accept the title, and that it was an imputation on the court to say that it was incompetent to declare the law on a point of law fully and adversely argued before it. The Master of the Rolls had, he said, repeatedly expressed his view that it was the duty of the court to decide questions of law which arose in determining the validity of titles, and though this view was later qualified in Burnell v Firth, ${ }^{73}$ it was restated by Lord Romilly (as he had by then become) in Mullings v Trinder. ${ }^{74}$ Ironically, the title upon which the doubt arose in the case was the same title as had been the subject of Pyrke v Waddingham. In contrast to the decision of Turner V-C, Lord Romilly ordered specific performance, expressing agreement with the principles enunciated by Turner V-C in Pyrke v Waddingham, and saying that the only point on which he disagreed with the Vice-Chancellor was in the application of those principles in the case. In that application, the more robust approach of Lord Romilly is apparent. Whereas Turner V-C had refused specific performance on the basis that, although he considered the title good, others might take a different view, Lord Romilly said he did not think any sensible

the Master of the Rolls, the position could have been different. Rede v Oakes (1864) 4 De G J \& S 505 is an instance where a decree of specific performance made by Lord Romilly MR was reversed by Turner and Knight Bruce LJJ on the ground that the title was doubtful.

68 (1852) 10 Hare 1. See also Glass v Richardson (1852) 9 Hare 698.

69 Collard v Sampson (1853) 4 De G M \& G 224; Freer v Hesse (1853) 4 De G M \& G 495; Cook v Dawson (1861) 3 De G F \& J 127; Sykes v Sheard (1863) 12 WR 117; Collier v McBean (1865) LR 1 Ch 81.

70 (1856) 21 Beav 337.

71 (1856) 22 Beav 573.

72 (1863) 32 Beav 615.

73 (1867) 15 WR 546.

74 (1870) LR 10 Eq 449. 
man would differ from him in the conclusion to which he had come, and was prepared to act on the basis of his own opinion.

Mullings $\mathrm{v}$ Trinder was decided not long after Turner LJ's departure from the Bench, and the views of his successors in the Court of Appeal in Chancery were more in keeping with those of Lord Romilly than of their predecessor. The difference of view between the new Lord Justices and Turner LJ is apparent in Beioley v Carter ${ }^{75}$ and Alexander v Mills, ${ }^{76}$ in both of which, ironically, the decision of Lord Romilly MR not to order specific performance, on the ground that the title was bad or doubtful, was overturned by the Court of Appeal in Chancery. The former case is notable for the reliance expressed by both Selwyn and Giffard LJJ on the Irish case of Sheppard v Doolan $n^{77}$ to show that the appellate court should determine the issue notwithstanding the decision of the court whose judgment was appealed, in contrast to the approach of Turner LJ as evidenced in a number of cases. ${ }^{78}$ The approach henceforth adopted in cases where title was doubtful was stated by James LJ in Alexander v Mills. While recognising that there could be cases in which a question of law was so doubtful that a court would not on its own view compel a purchaser to accept a title, James LJ said that as a general and almost universal rule, the court was bound as much as between vendor and purchaser as in every other case to determine what the law was and to take that to be the law which it so determined. Echoing the views expressed in Beioley v Carter, James LJ went on to say that the court could not escape from the duty to determine what the law was by saying that the decision of the court appealed against showed that any contrary view meant that the law was doubtful and the title should not be forced on a purchaser. Lest there were any doubt that a new era had arrived, in which the court was bound to decide issues of doubt, Malins V-C said in Bell $\mathrm{v}$ Holtby ${ }^{79}$ that the notion about doubtful titles not being forced on purchasers had disappeared. ${ }^{80}$ It was, he considered, settled that where doubtful cases of construction arose, whether of an Act of Parliament or an instrument such as a will, it was the duty of the court to remove that doubt by deciding it; and instead of feeling a doubt whether other judges at other times might think in the same way as the court, it was the duty of the court to assume that the decision arrived at would be followed, and that the view seen by the court now as correct would so be seen in the future.

75 (1869) LR 4 Ch 230.

76 (1870) LR 6 Ch 124.

77 (1842) 3 Dr \& War 1.

78 Cook v Dawson (1861) 3 De G F \& J 127; Sykes v Sheard (1863) 12 WR 117; Collier v McBean (1865) LR 1 Ch 81.

79 (1873) LR 15 Eq 178.

80 See also Forster v Abraham (1874) LR 17 Eq 351, Jessel MR saying that it was the duty of the court to give an opinion whether the title was good or bad. In Collier v Walters (1873) LR 17 Eq 252 the Master of the Rolls considered that decisions such as Collier v McBean (1865) LR 1 Ch 81 had been overruled by Alexander v Mills. Contrast however Palmer v Locke (1881) 18 Ch D 381 in which the question whether Alexander $\mathrm{v}$ Mills had overruled earlier authorities was left open by Lord Selborne LC, the Lord Chancellor going on to say that he did not understand the doctrine as set out in Pyrke $\mathrm{v}$ Waddingham had been displaced by later authorities. 


\section{No more doubtful titles?}

The new practice of resolving doubts can be seen clearly in a number of instances. In re Carter \& Kenderdine's Contract ${ }^{81}$ illustrates the point well because of the differing approaches of the trial judge and the Court of Appeal. ${ }^{82}$ The title was doubtful because of the existence of conflicting authorities on a point of law. At first instance North J dismissed the vendor's summons for a declaration that the title was good, saying that he could not follow both authorities, and in the circumstances he could not force the title on the purchaser. The Court of Appeal took a different view, overruling one of the authorities and declaring the title good, and requiring the purchaser to pay the costs for good measure. A similar situation arose in In re Thompson and McWilliams Contract, ${ }^{83}$ where, again, the court declared the title good despite conflicting authority. ${ }^{84}$

The views expressed in Alexander v Mills as to the duty of the court to resolve doubts had been limited to determining points of law. James LJ had considered that the exceptional cases in which the court would not resolve the doubt would relate chiefly to issues of construction of ill-expressed instruments. As we have seen, Malins V-C considered that the duty to resolve doubts extended even to these. Resolution of doubts arising on construction of some instrument on which the title depended did later take place. Not long after Alexander v Mills was decided, James LJ forced a title depending on construction of a will on a purchaser, though Wickens V-C, against whose decision the appeal was brought, had refused specific performance. ${ }^{85}$ Similarly, in In re Reilly \& Brady's Contract ${ }^{86}$ Meredith MR construed a will, saying that by so doing he was fulfilling the duty cast on him by Alexander v Mills, and went on to hold the title good. Again, in Johnson v Clarke ${ }^{87}$ the court determined the construction of a document which had created either a tenancy for life or a periodic tenancy in a third party, and went on to order specific performance..$^{88}$

Not only have the courts resolved doubts where the doubt arose on construction of some instrument on which the title depended, they have also gone beyond what James LJ envisaged by resolving questions where the doubt arises as to facts, notwithstanding that one reason why the court adopted the practice of refusing to order specific performance was that the purchaser might lack knowledge of the facts on which the title depended. ${ }^{89}$

81 [1897] 1 Ch 776.

82 See also In re Tanqueray-Williams \& Landau's Contract (1881) 20 Ch D 465.

83 [1896] 1 IR 356.

84 See also Osborne to Rowlett (1880) 13 Ch D 774.

85 Radford v Willis (1871) LR 7 Ch 7.

86 [1910] 1 IR 258.

87 [1928] 1 Ch 847.

88 See also In re Courcier \& Harrold's Contract [1923] 1 Ch 565.

89 The proposition that a purchaser could not be required to accept a title depending on a matter of fact had been rejected in Smith v Death (1820) 5 Madd 371 by Leach V-C who considered that while a purchaser could not be required to accept a title depending on a matter of fact which was incapable of satisfactory proof, one which was dependent on a fact which was capable of such proof and had been proved could be forced on a purchaser. 
Two cases may be noted. In MEPC Ltd $\mathrm{v}$ Christian-Edwards ${ }^{90}$ the doubt arose because some sixty years before the question of title arose between vendor and purchaser there had been a contract for sale of the land to a third party. It was unclear what had taken place thereafter. Notwithstanding that the doubt arose as to matters of fact which had taken place after the contract had been entered, the House of Lords held that the title was safe for the purchaser to accept, on the grounds that abandonment of the earlier contract could be presumed, and that at such a distance of time specific performance of the contract would not be ordered. A similar resolution of doubt arising because of facts had taken place much earlier in Kenna $\mathrm{v}$ Ritchie..$^{91}$ In that case the vendor's predecessor in title had entered a covenant not to allow an excess of water to pass from his land through a culvert on land of a third party. The purchaser entered a contract to purchase part of the land to which the covenant related, and the covenant would appear as a burden on the certificate of title the purchaser would receive. The court held nonetheless that this did not constitute a valid objection by the purchaser to the title, as because of the physical characteristics of the land the purchaser had agreed to buy, the covenant would not affect him. According to A'Beckett J, the title was one which showed a flaw until that flaw was negatived by proof of disputable facts, and that in such a case the court would, in an action between vendor and purchaser, examine the facts and come to a conclusion which would be binding on the purchaser although it would not be binding on third parties who might be interested in disputing the facts or establishing a view opposed to that which the court adopted.

Thus from a position where the Court of Chancery would refuse to order specific performance where a doubt existed, the pendulum had swung by the beginning of the twentieth century to one described by Lord Cozens-Hardy MR in Smith v Colbourne. ${ }^{92}$ The courts in modern times, he said, had not listened with favour to the defence that title was too doubtful to be forced on a purchaser and it was the duty of the court, unless in very exceptional circumstances, to decide the rights between vendor and purchaser, even though a third party would not be bound by the decision.

\section{Costs}

The award of costs lies in the discretion of the court. Usually the court will make an order for costs in favour of the party who is successful in the action. While the award of costs to the vendor in cases where the vendor is successful in a suit for specific performance is unobjectionable where the title is beyond doubt, it is less obvious that the purchaser should pay the costs of the vendor in a case where the court makes an order in favour of the vendor only after resolving a doubt in the vendor's favour. In this situation there is a doubt at the time the parties entered the contract, and it is not until the court resolves that doubt that the vendor can enforce the contract. The same reasoning applies if the doubt is resolved against the vendor and the title declared bad. Should the unsuccessful party pay the costs of the other party in such circumstances? It seems that notwithstanding the existence of a reasonable doubt on the title, if the court resolves the doubt in favour of the

90 [1979] 3 All ER 752.

91 [1907] VLR 386.

92 [1914] 2 Ch 533. 
vendor costs will, as a rule, be awarded to the vendor, the reason being to make it plain that the title is sound, ${ }^{93}$ though it seems harsh that the purchaser is in effect being penalised for having a doubt which was, until resolved, a reasonable one. Most of the cases in which costs have not followed the order have been ones in which the court has disapproved of the conduct of the vendor in not taking steps to clear his title before the proceedings were brought. ${ }^{94}$

\section{Not dead yet}

All is not however plain sailing. Modern cases can be found in which the courts have refused to determine the doubt one way or the other, and have adopted the previous practice of refusing specific performance where the title is doubtful, some judges making their preference for that practice known. ${ }^{95}$ In notable contrast to those instances mentioned above in which courts faced with conflicting authority chose one to the exclusion of the other and declared the title good is In re Thackwray and Young's Contract, ${ }^{96}$ in which, though the doubt arose as to a point of law, the court considered its own opinion on the point insufficiently strong to justify its forcing the title on the purchaser.

The case identified by James LJ in Alexander v Mills as likely to be one in which the court would not resolve a doubt arising on the vendor's title was one of construction of an ill-expressed instrument. In In Re Nichols and Von Joel's Contract, ${ }^{97}$ where the instrument whose construction was in doubt was a will, the court considered that where a simple means of resolving matters of construction existed, it would not be right to determine the matter in the proceedings between the vendor and the purchaser, but rather the proper course would be to adjourn the proceedings to allow a construction summons

93 Hall v May (1857) 3 K \& J 585; Micholls v Corbett (1865) 34 Beav 376 (Romilly MR saying that he would give the purchaser as good a title as he possibly could, by making him pay the costs); Hood v Lord Barrington (1868) LR 3 Eq 218; Osborne to Rowlett (1880) 13 Ch D 774 (though in the circumstances no award was made); In re Carter \& Kenderdine's Contract [1897] 1 Ch 776. In Woods v Hyde (1862) 10 WR 339 there is the somewhat unusual situation of a purchaser against whom a decree was made asking for the decree to be made with costs, Sir Hugh Cairns QC saying that "It would be a great blot on our title of we were not made to pay the costs." For cases in which specific performance was ordered, but without costs, see Radford v Willis (1871) LR 7 Ch 7; Cruikshank v Duffin (1872) LR 13 Eq 555; Osborne to Rowlett (1880) 13 Ch D 774; Poole v Coates (1842) 2 Dr \& War 493; Sheppard v Doolan (1842) 3 Dr \& War 1; Kenna v Ritchie [1907] VLR 386. See also In re Hogan \& Marnell's Contract [1919] 1 IR 422 where the purchaser was awarded costs where the case was adjourned to allow a construction summons to determine the doubt arising from a will.

94 In re Nichols \& Von Joel's Contract [1910] 1 Ch 43; Johnson v Clarke [1928] 1 Ch 847. See also Horton v Kurzke [1971] 2 All ER 577 and Lion Will Investment Ltd v Triple Will Ltd 1992-2 HKC 430.

95 Osborne to Rowlett (1880) 13 Ch D 774 (Jessel MR); Johnson v Clarke [1928] 1 Ch 847 (Maugham J). The view of Lord Selborne LC in Palmer v Locke (1881) 18 Ch D 381 that the doctrine explained in Pyrke v Waddingham had not been displaced by later authorities has already been noted.

96 (1888) 40 Ch D 34. See also Re Hollis Hospital Trustees and Hague's Contract [1899] 2 Ch 540

97 [1910] 1 Ch 43. 
to be taken out. ${ }^{98}$ Should the vendor decline the offer to adopt this course, he could expect that specific performance would be refused. ${ }^{99}$ In contrast to the view of Malins V-C in Bell v Holtby that the notion about doubtful titles had disappeared, Cozens-Hardy MR in In Re Nichols and Von Joel's Contract thought that the old rule was still in force, and ought arguably to be more readily adopted than it had formerly been. In other cases involving construction, the court has refused specific performance on the ground the court harboured sufficient doubt as to alternative constructions being possible. ${ }^{100}$

Cases where the matter in doubt involves some disputable question of fact, or of mixed law and fact, ${ }^{101}$ have been the most common situations where the court, notwithstanding the duty stated in Alexander $\mathrm{v}$ Mills to resolve doubts, has refused to order specific performance. ${ }^{102}$ In Nottingham Patent Brick \& Tile Co $\mathrm{v}$ Butler ${ }^{103}$ the question was whether the vendor had notice of a restrictive covenant or not when he purchased the property. In In re Handman \& Wilcox's Contract ${ }^{104}$ the question was whether the vendor had notice of circumstances possibly allowing a lease made under the Settled Land Acts to be impeached. In both cases the court held the title could not be forced on the purchaser, Cozens-Hardy LJ saying in the latter that while he would not hesitate to force on a purchaser a title depending on construction of a statute, even though his view differed from that of the court below, different considerations applied when the title depended on proof of a fact such as notice or the absence of it. Other cases in which the court has refused to force the title on the purchaser because of a doubt arising on the facts have involved questions as to whether the refusal of consent of the lessor to an assignment was unreasonable or not, ${ }^{105}$ and where the vendor had acquired trust property and the doubt arose from the rule preventing a trustee purchasing trust property. ${ }^{106}$

98 It was the absence of a similar means of resolving the doubt that forced Maugham $\mathrm{J}$ to determine the construction of an instrument in Johnson v Clarke [1928] $1 \mathrm{Ch}$ 847.

99 The same course was adopted in Wilson v Thomas [1958] 1 All ER 871, though Roxburgh $J$ thought that if the matter were one of construction not involving extrinsic evidence and not being very difficult, it might not be necessary to take this course. The difficulty of the purchaser being able to discover sufficient information about the circumstances of the devise in the testator's will persuaded Roxburgh $\mathrm{J}$ that the matter could not be dealt with in proceedings between the vendor and the purchaser.

100 Power v Barrett (1887) 19 LR Ir 450. See also In re Roe \& Eddy's Contract [1933] VLR 427 and Liu Kiu Leung v Tsang Mi Ling [2000] 422 HKCU 1.

101 In Wilson v Thomas [1958] 1 All ER 871 Roxburgh J was not disposed to treat mixed questions of law and fact as questions of law so as to be ones which it was the duty of the court to resolve, applying the principles in Alexander v Mills.

102 See In re New Land Development Association \& Gray [1892] 2 Ch 138, followed in Re Poppleton \& Jones' Contract (1896) 74 LT 582. See also In re Douglas \& Powell's Contract [1902] 2 Ch 296.

103 (1886) 16 QBD 778.

104 [1902] 1 Ch 599.

105 In re Marshall \& Salt's Contract [1900] 2 Ch 202.

106 Williams v Scott [1900] AC 499. Compare however Spencer v Topham (1856) 22 Beav 573 and Darvell v Basildon Development Corpn (1969) 211 EG 33 in which the court held the title good in similar circumstances. 


\section{Actions At Law}

Most of the developments concerning doubtful titles took place in the Court of Chancery, due to the especial remedy of specific performance available there. It should not be overlooked however that the Courts of Law were frequently involved in determining whether titles were good or bad. Commonly the action was one where a purchaser sought the return of his deposit, but actions by vendors who sought monetary relief rather than specific performance were of course brought also. The practice of the Courts of Law in cases where the title was doubtful developed to some extent with reference to what was happening in the Court of Chancery. The one significant difference of course was that the Courts of Law did not possess the discretion exercised by the Court of Chancery in granting or refusing relief. ${ }^{107}$

As in the Court of Chancery, the practice of the Courts of Law when faced with a title which was doubtful was not consistent. Early cases can be found showing an approach not dissimilar to that adopted for a long time in the Court of Chancery. In Hartley v Pehall ${ }^{108}$ the vendor was unsuccessful in an action of assumpsit against the purchaser as the doubt (whether the purchaser would be bound by a covenant) meant that the vendor had not shown his title was good. This was sufficient for the court to decide the case, without the court resolving the doubt. In other cases, ${ }^{109}$ purchasers were able to recover their deposits on the ground that the court would not require them to take a title which was in doubt, the courts referring in two of these ${ }^{110}$ to the practice of the Court of Chancery in suits for specific performance. Other authorities however show that in actions at law the court would hold the title either good or bad. ${ }^{111}$ That such was the duty of the Courts of Law was the understanding of Lord Blackburn, ${ }^{112}$ and is what took place in both Romilly $\mathrm{v}$ James $^{113}$ and Boyman $\mathrm{v}$ Gutch, ${ }^{114}$ Gibbs CJ in the former rejecting the argument that the purchaser was entitled to the return of his deposit if a doubt was cast on the title, pointing to the difference between the situation in the Court of Chancery and that in the Courts of Law, and Tindal CJ in the latter saying that the court was not a court of Equity where the vendor was seeking specific performance. Later however the pendulum appears to have swung back, and the practice of the Court of Chancery was seen as relevant by the Courts of Law, not in the exercise of any discretion, for there was none to exercise, but in determining the standard by which a title would be considered good or bad in the Courts of Law. It was the view of Pollock CB in Jeakes $\mathrm{v}$ White ${ }^{115}$ that where a question arose as to the meaning of a good

107 Oxenden v Skinner (1798) $4 \mathrm{Gw} 1513$.

108 (1792) Peake 178.

109 Elliot v Edwards (1802) 3 Bos \& Pul 181; Barnwell v Harris (1809) 1 Taunt 430; Wilde v Fort (1812) 4 Taunt 334; Curling v Shuttleworth (1829) 6 Bing 121. According to Alderson J in Boyman v Gutch (1831) 7 Bing 379 Curling v Shuttleworth had been doubted by the King's Bench.

110 Elliot $\mathrm{v}$ Edwards; Barnwell v Harris.

111 Romilly v James (1815) 6 Taunt 263; Boyman v Gutch (1831) 7 Bing 379.

112 Stevens v Austen (1861) 3 El \& El 685.

113 (1815) 6 Taunt 263

114 (1831) 7 Bing 379.

115 (1851) 6 Ex 873. 
and sufficient title, there had to be such a title as would be adopted by the Court of Chancery as a sufficient ground for compelling specific performance, so that where in an action by a lender for the costs of investigating a borrower's title, the title was found not to be such as would have been enforced by an order for specific performance, the lender was entitled to succeed. In Simmons v Heseltine ${ }^{116}$ an action was brought by a purchaser for the return of his deposit, following the refusal of the ViceChancellor to order specific performance of the contract at the suit of the vendor on the ground that title was doubtful. ${ }^{117}$ The action was successful, Cockburn CJ saying that he agreed in thinking that where title was dependent on a question of fact which it was impossible to regard as reasonably certain, the title could not be regarded as a good and sufficient title: to hold otherwise would, he said, be requiring the purchaser to elect between losing his deposit and purchasing a law suit.

The continuing need to distinguish between the practice of the Courts of Law and that of the Court of Chancery can be seen in a recent decision of the Federal Court of Australia. In Valoutin Pty Ltd $\mathrm{v}$ Furst ${ }^{118}$ a purchaser sought a declaration he had lawfully rescinded the contract and the return of his deposit, on the ground that the title was bad or doubtful. Finkelstein J, finding in favour of the vendor, said that the purchaser's action was an action at law, and the rights of the parties had to be determined by the principles applicable at law rather than the principles relating to doubtful titles in suits for specific performance. Even had the action been one for specific performance, the situation was not such as would have prevented the court from compelling the purchaser to accept it: the third party who might possibly have disputed the purchaser's title was before the court and all relevant facts had been ascertained, so that two of the reasons why specific performance had been refused in cases where the title was doubtful were not relevant.

\section{Registered Titles}

In the Brave New World of registration of title, the scope for doubtful titles should be much reduced. The legislation is supposed, after all, to provide a guarantee of title. Section 11 of the Land Registration Act (NI) 1970 provides that the register of title is conclusive evidence of the titles shown, and that the title of the registered owner is not, in the absence of actual fraud, affected by his having notice of any deed, document or matter relating to the title. Where someone is registered as full owner of a freehold estate with an absolute title, he becomes owner of that estate whether or not it was vested in him before then. ${ }^{119}$ What has been called the "statutory magic" works also in the case of someone registered as full owner of a leasehold estate with an absolute title, ${ }^{120}$ and, to a lesser extent, in cases where someone is registered with one of the other classes of title possible under the Act. ${ }^{121}$ No doubts should therefore arise as to whether such registered owners have the estates

\footnotetext{
116 (1858) 5 CB NS 554.

117 Heseltine v Simmons (1858) 6 WR 268.

118 [1989] 339 FCA.

119 Land Registration Act (NI) 1970, s 15(1).

$120 \mathrm{Ibid}, \mathrm{s} 20(1)$.

121 See ibid, ss 16-18, 21-23.
} 
mentioned. That does not mean however that there is no scope for doubts to arise in a sale of the land concerned. Doubts could arise as to whether the title of the registered owner remains in existence or has been extinguished by the adverse possession of the land by some third party; ${ }^{122}$ or because some third party asserts that the register contains errors and the possibility exists that the register could be rectified. ${ }^{123}$ Further, if the courts extend the concept of "title" to include matters such as planning and building control, ${ }^{124}$ the opportunities for doubts to arise will remain notwithstanding that the title in the traditional sense is registered and guaranteed. The possibility of the court declaring the title of the vendor doubtful in an action for specific performance by the vendor will therefore remain even when registration of title has been completed, albeit that the number of instances in which this will take place should be fewer.

\section{CONCLUSION}

The view that a title is either good or bad, and there should be no such thing as a doubtful title, undoubtedly has an appeal to it, apart from the obvious attraction of simplicity. If a court is asked to determine whether the vendor is entitled to specific performance of a contract, it seems reasonable that it should say either that the title is good, and the vendor is entitled to the order sought, or that it is bad, and he is not. Any intermediate position, in which the vendor is refused specific performance because the title is said to be doubtful, appears on the one hand to be avoiding the issue, and on the other to be creating the uncertainty which it is agreed should be avoided in this area. ${ }^{125}$ Insofar as the doubt arises as to a matter of law, it can rarely, if ever, be justifiable that the court should say, "This is what we think the law is, but others may take a different view, so we will not order specific performance". That seems to be an unwarrantable abnegation of the responsibility of the court. If one of the parties thinks the decision of the court is wrong, it can be appealed. The parties are however entitled to a decision one way or the other. Refusal of specific performance on the ground that the title is doubtful is of course a decision, but it is not one which determines the real issue between the parties. ${ }^{126}$ Where the doubt arises as to a matter of construction, or as to a matter of fact, the argument in favour of the court declaring the title good or bad is not as strong. The fact that third parties with an interest potentially adverse to the title are not before the court means that the court

See ibid, 53.

3 Ibid, s 69.

124 See Gosling v Anderson (1971) 20 EG 1117; Watkin v Wilson [1985] 1 NZLR 666; Pemberton Australia Pty Ltd v CPS Services Pty Ltd 1990 NSW LEXIS 10619; Davies-Smith v Superoo Pty Ltd 1994 TAS LEXIS 2164; Grand River Ltd v Asie Marketing Ltd [1990] 1 HKLR 297; Active Keen Industries Ltd v Fok Chi Keong 1994-2 HKC 67; Lui Kwok Wai v Chan Yiu Hing 1995-1 HKC 197; NG King Wai Terence v Qing Yuan Enterprises Ltd 19982213 HKCU 1; Chi Kit Company Ltd v Lucky Health International Enterprise Ltd [2000] 521 HKCU 1.

125 Mullings v Trinder (1870) LR 10 Eq 449; Mogridge v Clapp [1892] 3 Ch 382.

126 Note that in some cases the court was called on to determine the real issue between the parties rather than simply whether specific performance should be ordered, the title being doubtful: see Governors of the Charity for the Relief of Poor Widows and Children of Clergymen v Sutton (1860) 27 Beav 651; In re Huish's Charity (1870) LR 10 Eq 5; Wise v Piper (1880) 13 Ch D 848. 
will be putting the purchaser at risk if it declares the title good, and later those third parties, not bound by the court's decision, can show another court that their interests are valid and take precedence over that of the purchaser. Two points need however to be considered: first, the extent to which it is likely that someone else, such as another court or the Registrar of Titles, would reach a conclusion on the title at variance with that of the court now considering the matter; and secondly, the extent to which a purchaser is entitled to be assured that he is safe from risk before being ordered to take a title from the vendor.

The first of these issues is the easier to deal with. The question whether the Chief Land Registrar would be bound to take the same view of the title as the court was raised in MEPC Ltd $\vee$ Christian-Edwards, the land being in an area of compulsory registration. At first instance ${ }^{127}$ Goulding $\mathrm{J}$ dismissed the suggestion that a declaration by the court that a sufficient title had been adduced would be of practically conclusive value to the purchaser as a protection against any future claim by saying "That is a siren song to which I can only properly stop my ears." In the House of Lords, however, ${ }^{128}$ Lord Russell thought it inconceivable that in a case where a vendor has been held by the Court of Appeal or the House of Lords to have shown a good marketable title the Chief Land Registrar should hold that the vendor had shown something less. That must surely be correct, but it does not deal with the possibility that additional information is made available to whoever is later considering the title which is relevant to the title. It is also apparent from the cases in which appeals have been allowed that different judges may hold different views of the same title. Of the decision of the Lords in MEPC Ltd v Christian-Edwards (that there was no reasonable doubt that the purchaser would be safe, there being no prospect that the court would order specific performance of a contract made in 1912 with a third party) Emmet and Farrand say that practitioners may not find it an entirely satisfactory one on which to rely in similar cases of doubtful incumbrances, and go on to opine that solicitors should continue to raise requisitions as to doubtful incumbrances, but must then advise their clients to rely on their experience and their insurers as to the likelihood of enforcement. ${ }^{129}$ That leads to the second issue: whether specific performance should be ordered if in doing so the purchaser would be put at risk. Where it is possible for the vendor to undertake proceedings with third parties so as to determine the issue causing the doubt on the vendor's title, there is no need for the purchaser to have to rely on safeguards mentioned by Emmet and Farrand for protection. A means exists for getting rid of the doubt altogether. Where the doubt arises on construction of a will, there is nothing to prevent the vendor taking out a summons to determine the effect of the testator's disposition. In other situations a different means of resolving the doubt may exist which will have the same the effect of negating any risk from a third party. If so, why should the vendor be able to test the title in proceedings with the purchaser rather than with the third party? In Horton v Kurzke ${ }^{130}$ Goff J held that a vendor,

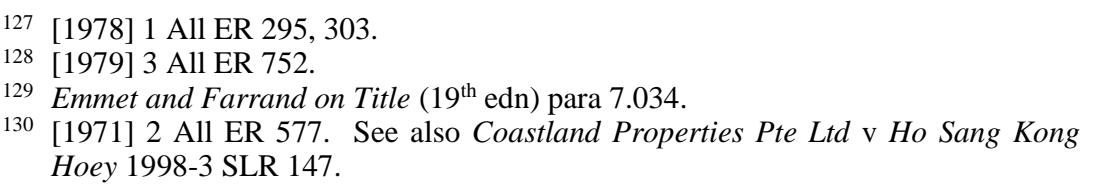


who chose to serve notice to complete on a purchaser who had raised objections to the title because of the existence of a claim by a third party as to grazing rights, was not entitled to do so: it was the vendor's duty to clear her title either by a vendor and purchaser summons or by awaiting the outcome of arbitration proceedings which were pending, and having failed to do so, she could not rely on the provisions of the contract allowing for service of the notice. Where a procedure exists therefore for the vendor to clear his title, there is no room for a doubtful title: that procedure ensures that the title will either be good or bad. The difficulty with such a view is that there will be cases where there is no simple means of disposing of the doubt between the vendor and a third party. In cases not involving construction of a will, or where arbitration with the third party is not a possibility, must the vendor institute proceedings against the third party for a declaration the defendant has no claim? Or would the vendor providing an insurance policy to cover the risk be sufficient? ${ }^{131}$

The cases on doubtful titles reveal two unsatisfactory aspects to the law governing the relations between vendor and purchaser. The first is the practice whereby the court in proceedings for specific performance by a vendor may refuse the order sought because the title is in doubt, failing to determine the real issue between the parties, namely, whether the vendor's title is good or bad. That failing seems largely to have been consigned to history, though the possibility of "exceptional cases" is preserved in some of the authorities so that there may yet be vendors who find that they are left to their remedies at law following a refusal by the court to make an order for specific performance on the ground that the title is doubtful. The other unsatisfactory aspect to the law in this area is still with us and concerns the assessment of the risk to the purchaser where some problem with the title has come to light. The cases show that among the judges the same title can be seen either as doubtful or as disclosing no reasonable doubt. There is no objective means by which doubt can be measured. It may be possible to identify doubts so irrational that all bar the purchaser raising them can see that the risk is non-existent or realistically so, and at the other end of the scale to agree that the doubt identified is one which is bound or almost certain to expose the purchaser to litigation with a third party. It may also be possible to say that the line between the two extremes is drawn where the doubt is reasonable. It may even be possible to agree with the view that matters would be improved "if those instructed to act for purchasers could be brought to realise that they would serve their clients better by exercising their common sense rather than by exhibiting their zealousness" and that "the time has come ... to put an end to the practice of magnifying difficulties which are really non-existent, a practice which frequently operates to keep apart a

131 See Manning v Turner [1956] 3 All ER 641; Lion Will Investment Ltd v Triple Will Ltd 1992-2 HKC 430. The practice of the court has usually been that purchasers would not be required to accept an indemnity from the vendor in suits for specific performance: see Balmanno v Lumley (1813) 1 V \& B 224; Paton v Brebner (1819) 1 Bli 42; Ridgway v Gray (1849) 1 Mac \& G 109; Re Heaysman \& Tweedy's Contract (1893) 69 LT 89; In re Weston \& Thomas' Contract [1907] 1 Ch 244. See however also Halsey v Grant (1806) 13 Ves Jr 73; Horniblow v Shirley (1806) 13 Ves Jr 81; Milligan v Cooke (1808) 16 Ves Jr 1. 


\section{Northern Ireland Legal Quarterly [Vol. 55, No. 1]}

vendor and purchaser themselves eager to conclude their bargain". ${ }^{132}$ The difficulty is that different minds may take different views of the same doubt, so how is a purchaser, or in reality his solicitor, to know without going to court whether the court will share his concerns or dismiss them as theoretical, fanciful, ridiculous or whatever other epithet the court chooses to signify they fall short of reasonable? One thing, it is suggested, is beyond reasonable doubt: faced with the choice between advising a purchaser not to proceed until the court has pronounced the title is safe notwithstanding the doubt, and risking an action for negligence if the purchaser is advised the doubt can be disregarded, many practitioners will prefer the former option.

132 Active Keen Industries Ltd v Fok Chi Keong 1994-2 HKC 67. 